\title{
Person-centered approaches in medicine: clinical tasks, psychological paradigms, and the postnonclassical perspective
}

\author{
Juan E. Mezzich ${ }^{\star}$, Yury P. Zinchenko**, Valeriy N. Krasnov***, \\ Elena I. Pervichko ${ }^{\star *}$, Maya A. Kulygina ${ }^{* * *}$ \\ ${ }^{*}$ Icahn School of Medicine at Mount Sinai, New York City, USA, \\ International College of Person-Centered Medicine, New York City, USA; \\ ${ }^{*}$ Lomonosov Moscow State University, Moscow, Russia; \\ ${ }^{* *}$ Moscow Research Institute of Psychiatry, Moscow, Russia
}

This article describes advances in the methodological means suggested by L. S. Vygotsky's cultural-historical concept in association with the theoretical model of person-centered diagnosis and the practical use of the construct for clinical psychology and medicine. To a great extent, these connections arise from the fact that the cultural-historical concept (because of its humanistic nature and epistemological content) is closely related to the person-centered integrative approach. The cultural-historical concept corresponds to the ideals of the postnonclassical model of scientific rationality with a number of "key" features. Above all it manifests its "methodological maturity" in coping with open selfdeveloping systems; being able to cope with such systems is most essential at the modern stage of scientific knowledge.

The article gives consideration to the "defining pillars" of the person-centered approach in modern medicine, to the humanistic traditions of the Russian clinical school, and to the high prospects of such mental constructs as the "subjective pattern of disease" and the "social situation of personal development in disease" within the context of personcentered integrative diagnosis.

This article discusses the need for implementation of a cross-cultural study of the subjective pattern of disease and its correlation with a particular social situation of personality development under disease conditions. The goals should be the development and substantiation of the model of the person-centered integrative approach, the enhancement of its diagnostic scope, and, subsequently, the improvement of the model of personcentered care in modern psychiatry and medicine.

Keywords: person-centered approach, person-centered integrative diagnosis (PID), Vygotsky's cultural-historical concept, subjective pattern of disease, social situation of development, postnonclassical model of scientific rationality, self-developing systems 
Currently, biological advances in medicine by far exceed developments in the humanistic disciplines because of new technologies and modern, updated equipment as well as the presence of various technical and organizational mediators in health care, including diagnosis and treatment. Under these conditions, the lack of adequate humanistic knowledge and humanistic norms (rooted primarily in psychology and ethics) bring about the deindividualization and dehumanization of medical care and turns it into a simple technical procedure (Krasnov, 2012). On the one hand, new evidence-based technologies in information processing facilitate the functioning of specialists and the validity of therapy methods, but, on the other hand, these technologies may create various obstacles in the doctor-patient relationship and in taking into account the patient's personal needs. Medicine seems to be increasingly "estranged" from the human being and is being transformed into a service with the technical intermediates of diagnosis and treatment.

Alongside these tendencies there is an increasingly manifested aspiration to focus on the integral study of individual functioning in disease, which is becoming one of the characteristic features of contemporary medicine. This focus is in line with the shift from a general nosocentric paradigm to a biopsychosocial and person-centered approach (Engel, 1982; Mezzich, 2006). The shift results in the introduction of a new category: a "person-centered integrative diagnostic model" (Salloum \& Mezzich, 2009). Within this paradigm a diagnosis is seen as a description of illness and of the positive aspects of health as they are affected by personality. A person-centered integrative diagnosis (PID) should provide information about both illness and the positive aspects of health. These aspects may include personal and social values and resources, the ability to adapt and compensate, as well as the quality of life of the patient (Sadler, 2005; Salloum \& Mezzich, 2009).

This article describes advances in the methodological means suggested by L. S. Vygotsky's cultural-historical concept as applied to clinical psychology and medicine in the development of a theoretical model of PID and the practical use of the construct.

We give consideration to the "defining pillars" of the person-centered approach in modern medicine, to the humanistic traditions of the Russian clinical school, and to the high prospects for such mental constructs as the "subjective pattern of disease" and the "social situation of the personal development in disease" within the context of PID.

\section{The Person-Centered Initiative in Modern Psychiatry}

Nowadays growing concern with modern medicine's excessive emphasis on organs and disease and its fragmentation and compartmentalization has led to a number of clinical developments that subscribe to broad biopsychosocial concepts, the integration of health and social services, the "recovery" of the whole person, and the "healing relationship" between clinicians and patients (McWhinney, 1989). As a result, the biographical and social context of the patient's condition combined with attention to personal, family, and care resources is receiving increasing attention.

Conventional health-care paradigms focusing just on disease and immediate care are often regarded as inadequate. A person-centered approach also facilitates 
attention to the positive aspects of health, such as resilience, resources, and quality of life. Such an approach is important for clinical treatment, prevention, and rehabilitation. It is also necessary to consider health promotion, a recently recognized key element of clinical care. This approach is consistent with the definition of health given by the World Health Organization (1999), which sees health as not being limited to the absence of illness or disease but involving a state of complete physical, social, and emotional well-being.

Personalized care is, thus, gradually becoming a major demand in modern medicine. Contextualization encompasses human diversity, and personalization requires attention to an individual's aspirations and life project. Respect for the patient's autonomy, values, and dignity represents a fundamental recognition of the patient's personhood and is an ethical imperative (Fulford, Christodoulou, \& Stein, 2011). Also crucial for clinical care is the thoughtful engagement of patients, both individually and in groups, including those critical of doctors, so as to reaffirm the dialogical basis of medical care. At the same time, there is renewed attention to the personhood of physicians and other health professionals with regard to the promotion of their wellness and their flourishing as whole persons well grounded in science and ethically committed to care and to help (Mezzich, 2007).

Psychiatry for the Person has been proclaimed a major World Psychiatric Association initiative (World Health Organization, 1999). A summarizing characterization of this international campaign is that it proposes looking at the whole person in context, as the center and goal of clinical care and public health.

This initiative was aimed at promoting a psychiatry of the person (of the person's whole health, covering both illness and positive aspects of health), a psychiatry for the person (for the fulfillment of the person's health aspirations and life project, not merely disease management), a psychiatry by the person (with psychiatrists and health professionals extending themselves as total human beings and not merely as healing technicians), and a psychiatry with the person (working respectfully and in an empowering manner with the person who consults). These ideas represent a conceptual shift in psychiatry and, potentially, in medicine at large (Mezzich, 2007).

\section{The Person-Centered Integrative Diagnostic Model}

Within this broad framework there is a need for a comprehensive diagnostic model as a cornerstone of patient care; in this model all relevant information about the patient's condition is integrated, with the goal being to support health restoration and to promote well-being. This integrative approach combines science and humanism to obtain a diagnosis of the totality of the person's health. This broader and deeper notion of diagnosis goes beyond the more restricted concepts of nosological and differential diagnoses (Salloum \& Mezzich, 2009). The proposed PID model, involving both a formulation and a process, employs all relevant descriptive tools (categorization, dimensions, and narratives) in a multilevel structure; engages the interactive participation of clinicians, patients, and families; and provides the informational basis for the person-centered integration of health care. Given the importance of diagnosis as a fundamental organizing clinical activity, a particular model of it must be consistent with the overall clinical model of interest. The pur- 
pose of the PID model is to facilitate and optimize person-centered care based on fundamental humanistic considerations.

A PID includes a theoretical model and its implementation on the basis of a practical clinical guide or manual. The clinical-care component is focused on the development of a set of guidelines for person-centered care and on the design of the curricula for person-centered training for psychiatrists and other health-care professionals.

A PID mandates that clinicians pay attention to the place of an individual's problems within the context of a standard nosology; they can then integrate the general and the particular circumstances affecting a disorder and also emphasize the value of and a positive notion of comprehensive health for the patient (Mezzich, 2007).

The new PID model, or schema, is as shown in Figure 1.

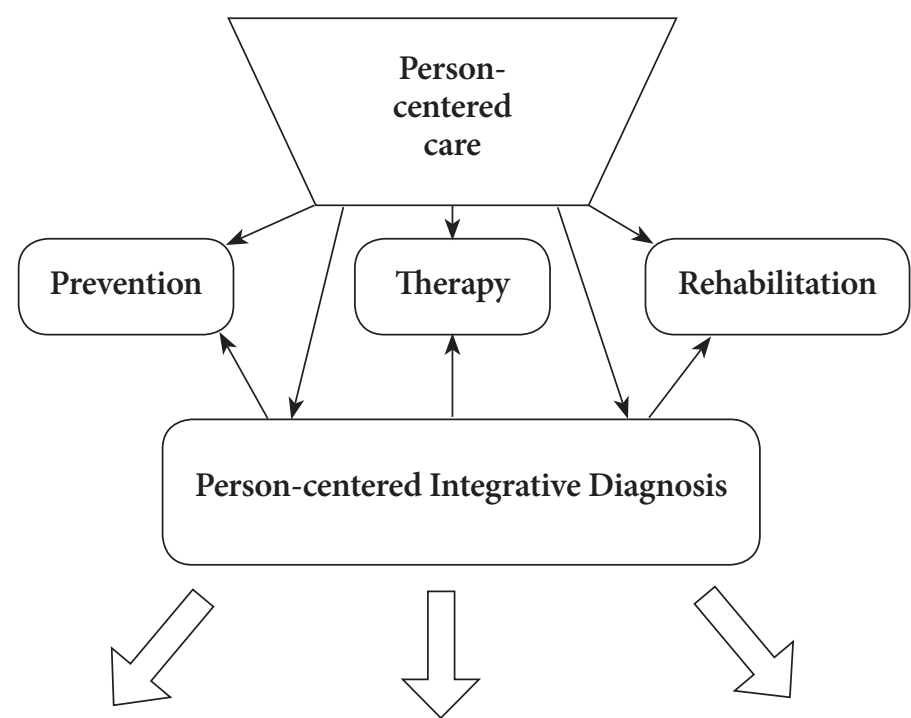

WHAT?
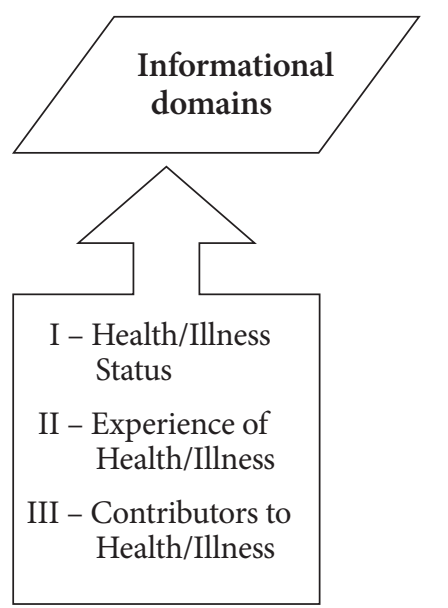

HOW?

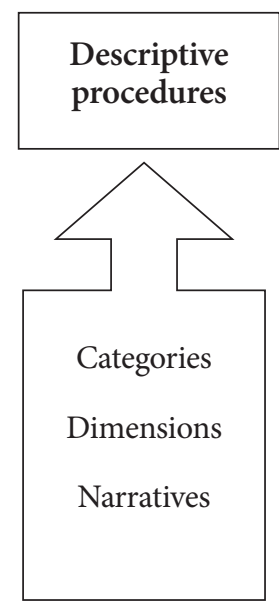

WITH WHOM?

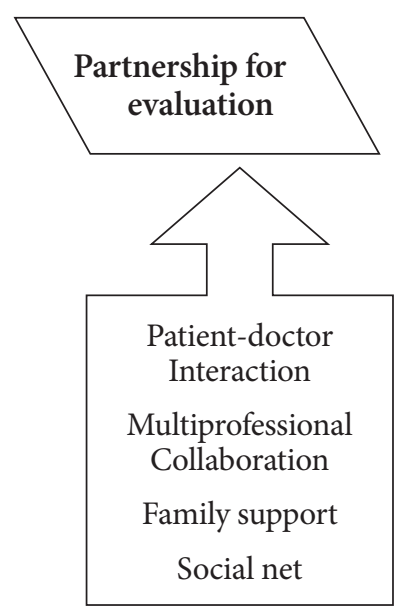

Figure 1. Person-centered integrative diagnosis domains. 


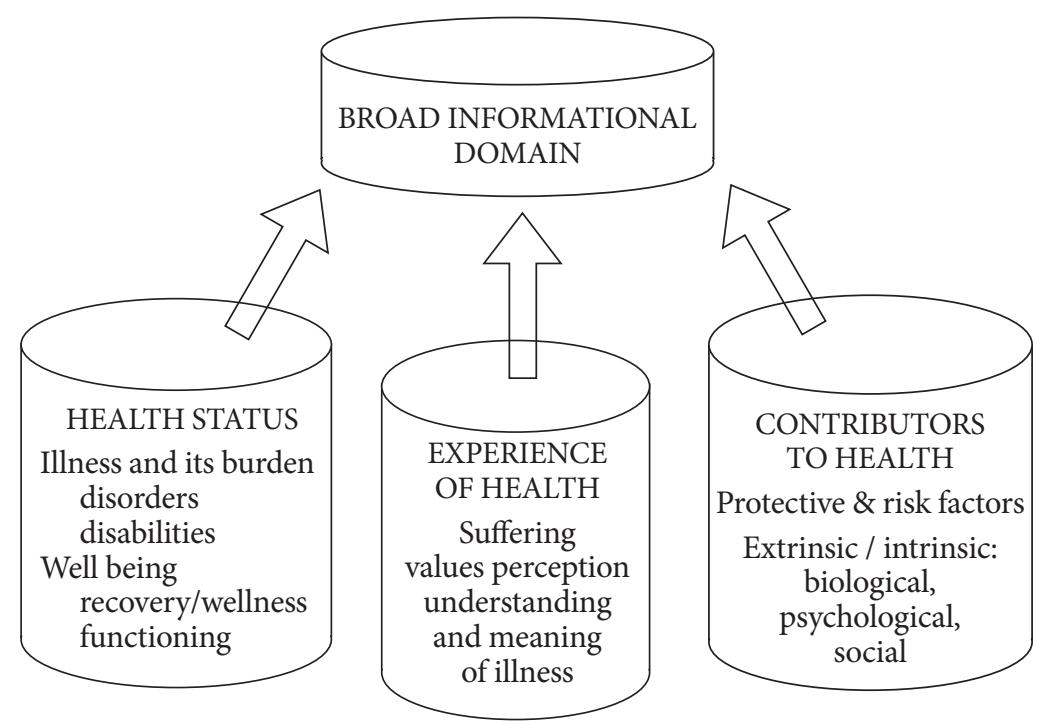

Figure 2. Broad informational domain.

The PID framework's first pillar corresponds to the question "What is diagnosed?" and is a broad informational domain. It covers both illness and positive health on three complementary levels: health status, experience of health, and contributors to health (see Figure 2).

The level of health status includes illnesses or disorders in both mental and physical forms; this category corresponds to nosological diagnosis. The domain level of experience of health comprises the patient's illness- and health-related values and experiences (Mezzich, 2008). It covers the experience of illness (including suffering and care) in the ill-health column and the experience of health (including quality of life, values, and the cultural formulation of identity and context) in the positive-health column. The domain level of contributors to health covers a range of intrinsic and extrinsic biological, psychological, and social risk factors, such as genetic vulnerability or stressors. It also covers inner and external protective factors, which include resilience and social support.

The PID model's second defining pillar (see Figure 1), pluralistic descriptive procedures, covers the descriptive tools to be employed and proposed to respond to the question "How might it be diagnosed?" The first tools are categories, particularly of a probabilistic type (Jablensky, 2005). The second descriptive tools are dimensions, which offer the opportunity to measure particular domains in a quantitative manner by using such instru of the information available also affords categorical assignment above a threshold ments as scales, tests, questionnaires. This use level. The third descriptive tools are narratives. This ideographic method offers the possibility of a deeper and richer description of a relevant domain. Narratives are most suitable for approaching and formulating the experience of health in order to allow the greatest flexibility and the possibility of delving deeply into the intricacies of each case. For this effect, narratives are more propitious than categories or dimensions. At the same time, narratives can be organized as needed 
to ensure and facilitate focused and ordered attention to important informational domains.

The third defining pillar of the PID model is the partnership for evaluation. Such a partnership is a fundamental element of person-centered care; it involves engagement, empathy, and empowerment as well as respect for the autonomy and dignity of the consulting person. In fact, it is essential for achieving a shared understanding that can be used in diagnosis and shared decision making for treatment planning.

Further development of the PID will involve the construction of a practical guide and application manual. It will translate and specify the theoretical model to provide a set of procedures for practical use; it will include (1) the structure, schemas, and procedures of the model, (2) the instruments to be used, and (3) the procedures to be employed for the assessment of the domains of the PID.

\section{Russian traditions of personalized care}

Russian medicine, especially Russian psychiatry, has longstanding, rich traditions of humanistic approaches with a focus on personality, including the mental patient's personality (Krasnov, 2012).

As long ago as the middle of the 19th century the founders of the Russian clinical school, S. P. Botkin, M. Ya. Mudrov, and G. A. Zakharjin, declared the key principle of individualized therapy: "To treat the person, not the disease", that dates back to antic times.

Psychiatrist and neurologist V. M. Bekhterev (1918) continued and developed this approach with ideas about the integrative, biosocial nature of the human being. These ideas emerged much earlier than George Engel's recognized concept of the biopsychosocial unity of the human being (1982). Bekhterev's colleague and disciple A. F. Lazursky (1912) distinguished the "endopsyche," which is the inborn foundation of the individual and includes temperament, character, and a number of other psychophysiological characteristics, and the "exopsyche," which is the system of relations between the person and the surrounding world. These concepts formed the foundation for his personality classification and were further developed by V. N. Myasishchev (1960) in his "psychology of relations." This concept postulated personality as a system of interactions between an individual and the social environment, with specific attachments, preferences, and values. In clinical practice, the psychology of relations was applied mainly in diagnosis and the treatment of neurotic disorders. In contrast to many psychodynamic approaches, it did not view the personality as defective and burdened with various hidden complexes but as the pinnacle of mental functioning, as a highly organized psychological system with self-awareness and the ability to control manifestations of disease. This system could be effectively used if properly supported by the therapist and accompanied by the correction of relations with the close environment.

Because of the contributions of the famous psychiatrists S. S. Korsakov, F. E. Rybakov, and others, several concepts had been developed by the beginning of the 20th century: the "principles of clinicism," which accentuated the patient's personality; cultural, moral, and spiritual values; and relations with the environment (Korsakov, 1901; Rybakov, 1917). In addition, the clinical tradition implied use 
of a multilevel, dynamic clinical analysis that combined the phenomenological approach with the global regularities of the morbid process. Personality and microsocial surroundings were also considered as a potential defense against disease. Thus, the humanistic approach to the patient was gaining priority in Russian medicine.

The evolution of the humanistic tradition in the Russian clinical school has always been nourished by achievements in psychological science. Korsakov reckoned that only acquaintance with the foundations of psychology provides an understanding of the disintegration of mental activity in a mentally ill person; he emphasized the importance of psychological features of personality for consideration in the provision of care. He began his lectures on psychiatry with the foundations of psychology. The same approach was followed by V. P. Serbsky, V. A. Gilyarovsky, Bekhterev, Rybakov, and others. They argued that every general practitioner needs psychological training. In 1885 the Moscow Psychological Society was established by a group of talented scientists who subsequently became its most distinguished members. Among them was the physiologist I. M. Sechenov, the naturalist and the most eminent science historian V. I. Vernadsky, and psychiatrists Korsakov, A. A. Tokarsky, Serbsky, P. B. Gannushkin, N. N. Bazhenov, and S. A. Sukhanov.

Since the second half of the 20th century the data of psychological diagnosis have been actively employed by Russian specialists (eminent Russian psychologists A. R. Luria, B. V. Zeygarnik, Yu. F. Polyakov, Myasishchev) both for differential diagnostics in clinical studies and for the treatment and rehabilitation of patients.

In the middle of the 20th century, D. E. Melekhov $(1963,1977)$ developed (on the basis of A. N. Leontyev's activity theory) a clinical conception of "functional diagnosis." Consideration of its basic theses may be of particular interest within this discourse.

\section{The clinical conception of functional diagnosis and its foundation in Leontyev's activity theory}

The idea of functional diagnosis was suggested by the Russian psychiatrist T. A. Geyer (1933). Originally the conception of functional diagnosis in Russian medicine was developed in the context of the medical examination of workers. In this case functional diagnosis was essential for a work prognosis. It was based on the study of the structure of, dynamics of, and ways of compensating for a psychological defect under particular working conditions.

Melekhov (1963) saw in Leontyev's activity theory a significant potential for rehabilitation of patients with severe and disabling diseases-for example, schizophrenia. His rehabilitation model was based on making use of the stronger and healthier facets of the personality, which could counteract deterioration, and this model proved productive in the prepharmacological era in psychiatry. The accent on the strong sides of personality allowed Melekhov to develop a productive treatment approach and the so-called labor rehabilitation of mental patients (Leontyev, 1975).

However, advances in patient rehabilitation in Russian medicine in the 1950s to 1970s paved the way for a revolution in the understanding of functional diagnosis. The focus switched to the personalities of patients and their adaptive-compensatory 
abilities and to the social situations that affect their lives (Kotsyubinsky \& Zaitzev, 2004; Volovik, 1975).

In accordance with modern views, functional diagnosis should be composed of the following four units (Kotsyubinsky \& Zaitzev, 2004):

1. a unit of premorbid adaptive potential (premorbid stability/sensitization of a person in the development of physical/mental disorders)

2. a psychological unit of mental adaptation, embracing at least such constructs as coping strategies, psychological defense mechanisms, the subjective pattern of disease, internal resources

3. a social unit of mental adaptation (patient's adaptation to social environment)

4. a unit of social support (family and other kinds of social networks)

Thus, functional diagnosis is a synthesis of the clinical and psychological assessment of a patient in real life; it provides a dynamic description of the patient's state and interaction with a particular social environment, and it reveals the basic compensatory strategies for coping with disease.

The concept of functional diagnosis is the principal point of similarity between the methodological approaches in clinical diagnostics developed within the Russian clinical school and modern, person-centered trends in medicine.

However, the long isolation of Russian science still makes most of its achievements unknown to the rest of the world.

Russian psychology employs an array of concepts and models similar to PID in its humanistic orientation as well as in the epistemological content of the model, and, above all, in the cultural-historical concept suggested by Vygotsky and its applications to clinical psychology and medicine.

\section{Vygotsky's cultural-historical concept: key principles regarding person-centered clinical practice}

The cultural-historical concept of mental development was introduced by Vygotsky in the 1920s and the beginning of the 1930s. It was further developed in the works of his committed students and disciples: Leontyev, Luria, P. Ya. Galperin, D. B. Elkonin, and others.

As is well known, the idea of the social-historical nature of human mentality and human consciousness, as opposed to naturalism in all shapes and forms, is one of the basic postulates of this approach.

Within the frame of the cultural-historical concept, personality is viewed as a hierarchical system of interconnected properties that developed in the course of interaction between the individual and the social environment and as the individual adopted existing cultural patterns (Vygotsky's "interiorization"). Personality development is associated with certain hereditary biological predispositions, but, principally, culture and social relations play a decisive role. Adoption of social and cultural traditions is at least as important as hereditary predisposition. However, character is shaped in interaction with the environment, although it also depends partially on genetics and heredity. In any case, the development of personality as 
the pinnacle of mental organization invariably occurs in interaction with the social environment, in confrontation with it, in yielding to its demands or resisting its pressures-all during activities aimed at changing external circumstances and at self-evolvement.

Naturally, all the definitions of personality in Russian psychology encompass, besides general outlook, cultural and social values, social range and motivation, and the development of self-awareness. A mature personality should have a differentiated self-awareness and realize the unity of self and the environment.

\section{The subjective pattern of disease}

The fundamentals of Vygotsky's cultural-historical concept of mental development are believed to be relevant for the analysis of the psychological construct of a patient's reaction to disease, or the patient's subjective pattern of disease. In Russian clinical medicine, psychiatry, and clinical psychology, this term covers a whole set of the patient's subjective ideas about his/her disease.

The term was introduced into the scientific vocabulary in 1935 by the Russian clinician Roman Luria, the father of Alexander Luria, who was the founder of neuropsychology. Roman Luria developed theses of the German clinician Alexander Goldscheider (1898), who argued that clinical diagnosis requires consideration of the subjective component within the general pattern of a somatic disease, or the "autoplastic picture of disease" (Goldscheider, 1898).

Roman Luria defined the term as follows:

[The subjective pattern of disease is] all that the patient experiences and suffers, the whole set of his/her sensations, not only local painful ones, but referring to the general state of health, the introspection, the notion of disease and its causes-the interior universe of the patient, which embraces intricate combinations of perception and sensation, emotions, affects, conflicts, mental experience and traumas. (Luria, 1977, p. 38)

Today Russian psychology rests on vast experience studying patients' ideas about their diseases; these studies employed the notion of the subjective pattern of disease (Luria, 1977; Nikolayeva, 1987; Sokolova \& Nikolayeva, 1995). A considerable number of works by the Moscow State University professors V. V. Nikolayeva and A. Sh. Tkhostov and their disciples were conducted within the cultural-historical approach to human mentality and bodily phenomena. They established solid theoretical underpinnings for clinical-psychological studies of the subjective reflection of various aspects of illness in patients' minds within the context of somatic and mental disorders (Nikolayeva, 1987; Sokolova \& Nikolayeva, 1995; Tkhostov, 2002).

The studies revealed that the subjective pattern of disease is a complex structure, comprising at least four levels of mental reflection of a disease:

1. the level of sensations

2. the emotional level, which includes the emotional reaction to diverse symptoms and to disease as a whole and its consequences

3. the cognitive level, which includes the patient's awareness of the disease, its conception, causes, and after-effects 
4. the motivational-personality level, which is affected by the attitude of patients to their diseases and to imminent changes in their way of life

Features of the motivational-personality level dictate, to a great extent, patients' behavior and their compliance; these features provide for the actualization (or nonactualization) of patient activities aimed at rehabilitation and the protection of health.

The subjective pattern of disease is an integral structure within which all elements are interconnected and mutually affected; its dynamics may be regarded as an important indicator of transformations in a patient's personality (Nikolayeva, 1987; Sokolova \& Nikolayeva, 1995).

The cultural-historical paradigm implies consideration of the subjective pattern of disease during the process of its formation as "an individual semiotic system, generated by the patient, ... who has adopted a certain system of common representations" (Tkhostov \& Raizman, 2005, p. 104). It can be regarded as a special form of cognitive activity (somatoperception) subject to general psychological regulations (Tkhostov, 2002; Arina, 2009).

Studies of embodiment and the formation of the subjective pattern of disease, conducted within the cultural-historical approach, have demonstrated the sequence of stages and have named the factors due to which the originally diffuse, hardly localized sensations from internal organs assume concrete shape; these sensations are verbalized and "fit" the "concepts of disease" and the "mythology of disease" established in any culture. The concepts and mythology of disease involve understanding the causes and risks of the disease, its treatments, and outcome. In other words, these studies demonstrated how "an individual concept of disease" - that is, the subjective pattern of disease-may be evolved from the social and cultural experience of the patient.

When we turn to the formulation of clinical problems, it can't be ignored that in most cases illness is perceived by the subject as a stressful situation. It can be regarded as imposing restrictions on one's usual ways of functioning and developing; it can even pose the risk of losing one's life. All these factors may actualize a subject's inefficient psychological defense mechanisms and coping strategies and may generate inadequate behaviors regarding treatment, thus hampering compliance and reducing the effectiveness of treatment. This situation brings the subjective pattern of disease and similar phenomena into the limelight not only among researchers but also among clinicians and psychiatrists.

We can sort into three main groups the variety of factors governing the formation and the dynamics of the subjective pattern of disease (especially a chronic somatic disease) and shaping its type and degree of adequacy:

- factors connected with the character of the illness: severity, duration, positive/negative prognosis, etc

- personal factors: premorbid features of the patient's personality, mechanisms of psychological defense, coping strategies, motivational value-semantic setting

- social-psychological factors: the level of the patient's social adjustment, the permanency and reliability of social support, the reactions of others, shifts in the social status of the patient 
The specific constellation of these factors, as a whole, defines the "social situation of personality development under disease conditions" (Sokolova \& Nikolayeva, 1995). Hence, a particular subjective pattern of disease is specified by a concrete social situation of personality development in this context.

\section{The construct "social situation of personality development under disease conditions"}

The category of the social situation of development is among the basic concepts introduced by Vygotsky's cultural-historical conception of mental development for consideration of the mechanisms of mental development (Bozhovich, 1968; Burmenskaya, 2002; Elkonin, 1960; Karabanova, 2004; Vygotsky, 1993, 1998).

The social situation of development ... does not merely imply the conditions of development, it represents ... a particular correlation of internal processes of development with external conditions, which are typical for every age. ... They provide for both mental development at a certain stage and psychological innovations appearing in the period. (Bozhovich, 1968, p. 152)

Disintegration of the existing social situation of development and emergence of a new one substantiate the crises in personality development.

As was stated above, the formulation of clinical objectives requires an understanding that the objectification of any chronic disease will put an individual in peculiar psychological circumstances. The illness may bring a crisis into the general line of development; such a crisis will affect the whole lifestyle of the patient.

In the 1980s Russian psychologists began to assume that the analysis of the dynamics of the subjective pattern of disease and the transformation of the social situation of personality development in this context could be employed as a methodological instrument for the study of personality development under the conditions of disease. The substantiation of this hypothesis is regarded as a most important achievement in studies of the subjective pattern of disease undertaken by Russian clinical psychology. It reinforces Vygotsky's idea that development continues in the new circumstances of disease; this thesis was worked up by and received further proof in the works of his followers (Sokolova \& Nikolayeva, 1995).

\section{Conclusions and perspectives}

Our analysis of the basic ideas of the person-centered approach in modern medicine, of the humanistic traditions of the Russian clinical school, and of the fundamentals of Vygotsky's cultural-historical concept (in their application to clinical psychology, clinical medicine, and psychiatry) leads to the following conclusions.

1. The development and realization of a person-centered approach to diagnosis and treatment is in line with the general tendency toward the humanization of modern medicine and the reshaping of its principal nosocentric paradigm into a biopsychosocial one. The epistemological content of the tendency suggests consideration of a number of methodological principles that bring the patients' personalities into focus; these principles comprise patients' individual and typological 
features, as well as a set of their values and attitudes toward themselves, their illness, and the environment.

One of the key principles is the principle of subjectivity. This principle is an expressed consideration of the internal space of an individual, his/her needs and demands, self-consciousness, and control over his/her development (in this case we are dealing with development under disease conditions) - all these qualities are realized in clinical practice within the individual approach, which rejects "conveyer-belt" technology.

The principle of systemicity assumes patients' investigation of the diversity and interplay of their manifestations. This principle implies the unanimity of the somatic and the mental within a social context; it is verbalized in a widely known line: "To treat the person, not the disease." Realization of this principle requires both a hierarchy of levels of the mental reflection of a disease and a gradual, logical approach to diagnosis and to therapy. The contemporary stage of scientific knowledge takes it for granted that an individual and his/her psyche should be placed among the most sophisticated of known systems-that is, open self-developing systems - and that the very existence of a human is polysystemic (Styopin, 2003, 2011).

The idea of a systemic approach implies the principle of determinism, although epistemologically it is important to "break" with a linear determination in favor of a "probabilistic" and "multiple-factor" one, which is exceedingly important for the matter at hand.

Another principle is the development principle (because systems exist only in development and through the development process). This principle makes it possible to care for the dynamics of individuals, with consideration for their adaptivecompensatory abilities and internal resources. Development may take the way of progress or of regress, but illness does not prevent the further development of personality, although it may interfere by imposing specific limiting conditions (Vygotsky, 1993, 1998).

All these principles lead us to one more principle-the principle of partnership. It implies that to complete the therapeutic effect we need a polyprofessional collaboration of specialists and cooperation with the patients and their environment.

2. The review of the traditions of the Russian clinical school reveals antecedents for the establishment of the above-mentioned methodological principles. We should take into account the ideas of humanism, holism, and psychological insight, which form the basis for diagnostic and therapeutic models in Russian medicine and psychiatry; the Russian clinical school postulated the importance of the individual features of the person in the formulation of a "detailed" diagnosis in order to provide a prognosis for the further development of personality in the new circumstances of disease. The model of functional diagnosis is an example of such personcentered systemic approaches.

3. Vygotsky's cultural-historical concept, in its application to clinical psychology and medicine, may be regarded as a relevant theoretical methodological basis for the development of models of person-centered approaches to diagnosis and treatment. The cultural-historical concept (because of its humanistic nature and epistemological content) is closely related to the model of PID, and it corresponds 
to the ideals of the postnonclassical model of scientific rationality because it has a number of key features. Above all, it manifests its "methodological maturity" in coping with open self-developing systems, a quality that is most essential at the modern stage of scientific knowledge (Pöppel \& Wagner, 2012; Prigogine, 1989; Prigogine \& Stengers, 1984; Styopin, 2003, 2011). This quality, in turn, provides for the concept's applicability to a wide range of theoretical and practical issues in interdisciplinary studies, to take the overlapping research in clinical psychology and medicine as an example. Psychological syndrome analysis is one of the perspective methods in this context. This method, originally borrowed by Vygotsky from medical studies, gained in his works another, quite different interpretation. This approach has been proven effective in clinical psychological studies. Its postnonclassical worldview is regarded as adequate given the contemporary level of science. It lays the foundation for the instrumental support of mental studies (Zinchenko \& Pervichko, 2012a, 2012b).

4. To indicate possibilities for further research in the context of the present discourse, it is important to point out that such psychological constructs as the subjective pattern of disease and the social situation of personality development under disease conditions exhibit considerable theoretical methodological potential for realization of the PID model. Particular concern, we presume, is attached to the enhancement of "psychological equipment" for such an analysis. The social situation of personality development under disease conditions, as a specific psychological phenomenon that has come "to represent a peculiar correlation of internal processes of development and external conditions" (Bozhovich, 1968, p. 152), should be the focus of a separate study. It may develop into a specific "research technique," employed for the analysis of the "operation" of various social factors in personal space (Mezzich, 2007; Salloum \& Mezzich, 2009).

5. To conclude, we should note as a possibility a cross-cultural study of the subjective pattern of disease and its correlation with a particular social situation of personality development under disease conditions. Such a study would attempt to develop and substantiate of the PID model, to enhance its diagnostic scope, and, consequently, to improve person-centered care in modern psychiatry and medicine.

\section{References}

Arina, G. A. (2009). Psihosomaticheskyj simptom kak fenomen kul'tury [A psychosomatic symptom as a cultural phenomenon]. In V. V. Nikolayeva (Ed.), Psihosomatika: Telesnost' i kultura [Psychosomatics: Corporality and culture] (pp. 23-34). Moscow: Akademicheskij proekt.

Bekhterev, V. M. (1918). Obschie osnovy reflexologii [General basis of reflexology]. Petrograd: Izdanie Rikkera.

Bozhovich, L. I. (1968). Lichnost' i ejo formirovanije v detskom vozraste [Personality and its formation in childhood]. Moscow: Prosveshhenie.

Burmenskaya, G. V. (2002). Vozrastno-psihologicheskij podhod v konsul'tirovanii detej i podrostkov [An age-related psychological approach to consultations with children and adolescents]. Moscow: Izdatel'skij centr Akademija.

Elkonin, D. B. (1960). Detskaya psihologiya [Child psychology]. Moscow: Prosveshhenie. 
Engel, G. L. (1982). The biopsychosocial model and medical education: Who are to be the teachers? New England Journal of Medicine, 306(13), 802-805. doi: 10.1056/NEJM198204013061311

Fulford, K.W.M., Christodoulou, G. N., \& Stein, D. J. (2011). Values and ethics: Perspectives on psychiatry for the person. International Journal of Person Centered Medicine, 1, 131-133. doi: 10.5750/ijpcm.v1i1.33

Geyer, T. A. (1933). Trudosposobnost' pri shizofrenii [Work capacity in the case of schizophrenia]. In Sovremennye problemy shizofrenii [Modern problems of schizophrenia] (pp. 106111). Moscow: Biomedgiz.

Goldscheider, A. (1898). Gesammelte Abhandlungen [Collected treatises]. Bd. 1-2. Leipzig: Barth.

Jablensky, A. (2005). Categories, dimensions and prototypes: Critical issues for psychiatric classification. Psychopathology, 38, 201-205. doi: 10.1159/000086092

Karabanova, O. A. (2004). Psihologiya semejnyh otnoshenyj i osnovy semejnovo konsul'tirovaniya [The psychology of family relations and the foundation of family counseling]. Moscow: Gardariki.

Korsakov, S. S. (1901). Lektsii po psihiatrii. [Lectures on psychiatry]. Moscow: Moscow University.

Kotsyubinsky, A. P., \& Zaitzev, V. V. (2004). Funkcionalnyj diagnoz: Teoreticheskaya konstrukciya ili realnyj fenomen? [Functional diagnosis: Theoretical construct or the real phenomenon?]. Obozrenie Psihiatrii i Medicinskoj Psihologii Imeni V. M. Bekhtereva [V. M. Bekhtereva review of psychiatry and medical psychology], 1 (1). Retrieved from http://old.consiliummedicum.com/media/bechter/04_01.

Krasnov, V. N. (2012). Personality in Russian psychology and psychiatry. International Journal of Person Centered Medicine, 2(1), 104-108.

Lazursky, A. F. (1912). Obschaya i experimentaljnaya psihologia. [Psychology, general and experimental]. St. Petersburg: Psychoneurologichesky Institut.

Leontyev, A. N. (1975). Deyateljnostj. Soznanie. Lichnostj. [Activity. Consciousness. Personality]. Moscow: Politizdat.

Luria, R. A. (1977). Vnutrennyaya kartina boleznej $i$ iatrogennye zabolevaniya [The subjective pattern of disease and iatrogenic disorders]. Moscow: Medicina.

McWhinney, I. R. (1989): Family Medicine: A Textbook. Oxford: Oxford University Press.

Melekhov, D. E. (1963). Klinicheskie osnovy prognoza trudosposobnosti pri shizofrenii [Clinical basics of the work-capacity forecast in the case of schizophrenia]. Moscow: Meditsinskaya

Literatura.

Melekhov, D. E. (1977). Problema defekta v klinike i reabilitacii bol'nyh shizofreniej [The defect problem in the clinic and the rehabilitation of patients with schizophrenia]. In Vrachebnotrudovaja jekspertiza i social'no-trudovaja reabilitacija lic s psihicheskimi zabolevanijami [Medical-labor expertise and the social and work-related rehabilitation of people with mental diseases] (pp. 27-41). Moscow: Medicina.

Mezzich, J. E. (2006). Institutional consolidation and global impact: Towards a psychiatry for the person. World Psychiatry, 5, 5-66.

Mezzich, J. E. (2007). Psychiatry for the person: Articulating medicine's science and humanism. World Psychiatry, 6(2), 1-3.

Myasishchev, V. N. (1960). Lichnostj i nevrozy [Personality and neuroses]. Leningrad: Leningrad University.

Nikolayeva, V. V. (1987). Vliyanije hronicheskoj bolezni na psihiku: Psihologicheskoe issledovanie [The impact of chronic illness on the psyche: Psychological research]. Moscow: Moscow University Press. 
Pöppel, E., \& Wagner, B. (2012). Von Natur aus kreativ [By nature creative]. Munich: Hanser. doi: $10.3139 / 9783446432864$

Prigogine, I. (1989, August). The philosophy of instability. Futures, 396-400.

Prigogine, I., \& Stengers, I. (1984). Order out of chaos: Man's new dialogue with nature. New York: Bantam Books.

Rybakov, F. E. (1917). Dushevnye bolezni. [Mental diseases]. Moscow: Izdanie M. Anikina.

Sadler, J. (Ed.). (2005). Values and psychiatric diagnosis. Oxford: Oxford University Press.

Salloum, I. M., \& Mezzich J. E. (Eds.). (2009). Psychiatric diagnosis: Challenges and prospects. Oxford: Wiley-Blackwell.

Sokolova, E. T., \& Nikolayeva, V. V. (1995). Osobennosti lichnosti pri pogranichnyh rasstrojstvah $i$ somaticheskih zabolevaniyah [Personality characteristics in borderline disorders and somatic diseases]. Moscow: SvR-Argus.

Styopin, V. S. (2003). Samorazvivajuwiesja sistemy i postneklassicheskaja racional'nost' [Selfdeveloping systems and postnonclassical rationality]. Voprosy Filosofii [Issues in Philosophy], 8, 5-17.

Styopin, V. S. (2011). Istorija i filosofija nauki [History and philosophy of science]. Moscow: Academic Project.

Tkhostov, A. Sh. (2002). Psihologija telesnosti [The psychology of corporality]. Moscow: Smysl.

Tkhostov, A. Sh., \& Raisman E. M. (2005). Subjektivnyj telesnyj opyt i ipohondriya: Kul'turnoistoricheskyj aspect [Subjective physical experience and hypochondria: The cultural-historical aspect]. Psihologicheskyj jurnal [Psychological journal], 26(2), 102-107.

Volovik, V. M. (1975). Funkcional'nyj diagnoz v psihiatrii i nekotorye spornye voprosy psihiatricheskoj diagnostiki [Functional diagnosis in psychiatry and some issues of psychiatric diagnostics]. In M. M. Kabanova, N. M. Vasjukova, \& R. A. Zachepickogo (Eds.), Teoretikometodologicheskije problemy klinicheskoj psihonevrologii [Theoretical and methodological issues in clinical psychoneurology] (pp. 79-90). Leningrad: V. M. Bekhterev Scientific Research Institute.

Vygotsky, L. S. (1993). The diagnostics of development and the pedological clinic for difficult children. In R. W. Rieber \& A. S. Carton (Eds.), The collected works of L. S. Vygotsky. Vol. 2: The fundamentals of defectology (abnormal psychology and learning disabilities) (pp. 241291). New York: Plenum Press. doi: 10.1007/978-1-4615-2806-7

Vygotsky, L. S. (1998). The problem of age. In R. W. Rieber (Ed.), The collected works of L. S. Vygotsky. Vol. 5: Child psychology (pp. 187-206). New York: Plenum Press. doi: 10.1007/9781-4615-5401-1

World Health Organization. (1999). WHO's new global strategies for mental health (Factsheet 217). Geneva: World Health Organization.

Zinchenko, Y. P., \& Pervichko, E. I. (2012a). The methodology of syndrome analysis within the paradigm of "qualitative research" in clinical psychology. Psychology in Russia: State of the Art, 5, 157-184. doi: 10.11621/pir.2012.0010.

Zinchenko, Yu. P., \& Pervichko, E. I. (2012b). Postneklassicheskaja metodologija v klinicheskoj psihologii: Nauchnaja shkola L. S. Vygotskogo-A. R. Lurija [Postnonclassical methodology in clinical psychology: Vygotsky-Luria school]. Nacional'nyj Psihologicheskij Zhurnal [National psychological journal], 2(8), 42-49. 